\title{
THE GLORY OF YHWH IN THE OLD TESTAMENT WITH SPECIAL ATTENTION TO THE BOOK OF EZEKIEL ${ }^{1}$
}

\author{
Pieter de Vries
}

This study focuses on the use of פָּ in in the Old Testament and especially in the book of Ezekiel. The specific approach of this study is

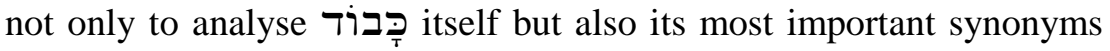
as well as its main equivalent in Aramaic, ?ִקר: Biblical texts are approached from a canonical perspective, and the synchronic approach prevails over the diachronic.

Chapter 1. Besides surveys of the use of כָָּ ordered according to several categories, overviews are given of the frequency and

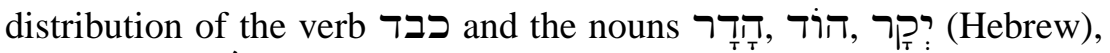

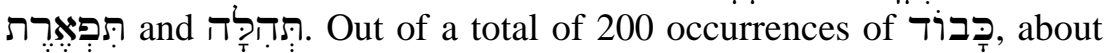
one hundred are directly related to YHWH. Two verbs are used most

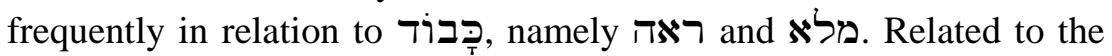

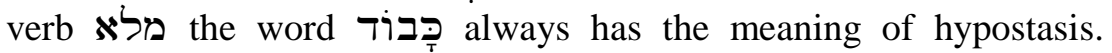
Connected with ראה it can have the meaning of God's saving and judging activity in history and eschatology, but also in this case it has primarily the meaning of hypostasis. Chapter 2 analyses the semantic

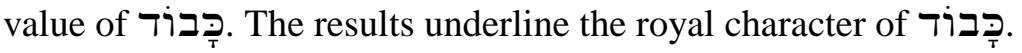

In Chapter 3 the occurrences of exception of the book of Ezekiel are considered. In Exodus to Numbers

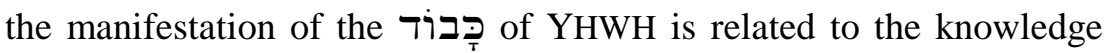
that YHWH is God. The glory of YHWH is especially revealed in the exodus from Egypt. The ultimate goal of the exodus is the dwelling of YHWH's כָָּ iָ in the tabernacle. From Exodus 16 to Numbers 20 the

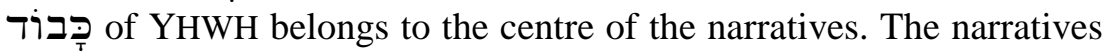
make clear that the כָָּ of YHWH that came down to Sinai took its

1 Pieter de Vries (Ph.D. dissertation, University of Amsterdam, 2010). Supervisor: Prof. Dr. Athalya Brenner. Trade edition: Pieter de Vries, De heerlijkheid van JHWH in het Oude Testament en in het bijzonder in het boek Ezechiël (Heerenveen: Groen, 2010). 
permanent abode in the tabernacle. In Exodus to Numbers the כבָָ of YHWH must be interpreted as a hypostasis that has the appearance of fire and light. Apart from Exodus 33, the portrayal of the YHWH as hypostasis is abstract and cannot be visualised; but here, clearly, the פָָּּרד of YHWH has the appearance of a man.

In the Former Prophets we find almost all the occurrences of in the narrative of the ark's loss and return. The narrative's message is that the power and presence of YHWH and his glory cannot be completely identified with the ark as its physical symbol. According to the presentation of Israel's history in the book of Kings, since the ark was brought to Jerusalem the city became the place of YHWH's throne on earth. In the temple dedication narrative (1 Kgs 8:1-9:9) there is

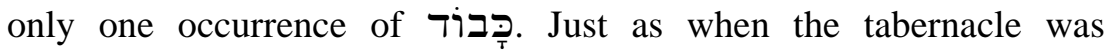

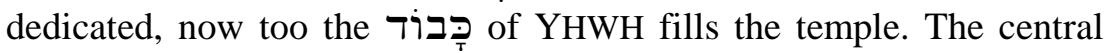
place of פָָּ in Isaiah cannot be understood apart from the vision of Isaiah's call for prophecy (Isa. 6). In it, the כָָּ כָוֹד of YHWH fills the earth. Chapter 35 can be read as a foretaste of chapters 40 onwards. The glory of YHWH is portrayed as manifested in the new exodus. The new exodus and its glory are connected with a complete renewal of nature; a theme specific to Isaiah, particularly its second part. In Isaiah 40:1-8 we find an extension of the vision of Isaiah's call as prophet. In

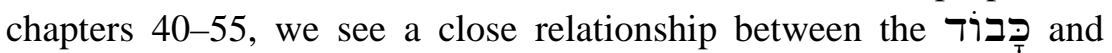

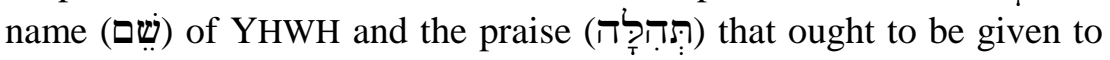
him. Chapters 60-62 form the centre of Isaiah 56-66. In these chapters the restoration of Zion is foretold: Zion will bathe in the glory of YHWH, a glory portrayed in terms of the rising sun.

Within the Minor Prophets, Habakkuk, Haggai and Zechariah are especially important for the כָּבוֹד of YHWH theme. Haggai's theme concerns the rebuilding of the temple. The prophet tells his audience that the glory of the second temple will exceed the glory of the first, and that all nations will bring their glory to it. There are two

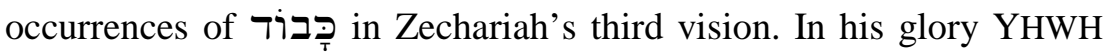
will dwell in the restored Jerusalem.

In the Psalms the כָָּ must be related both to YHWH's acts and to his attributes, and appears in several contexts. Usually it has to do with God's acts as manifested in creation, history and eschatology. In some cases it is possible to argue that the meaning of hypostasis is latently

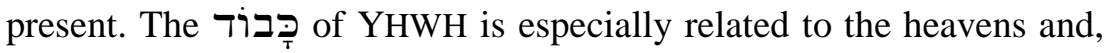
in the eschatological future, will be manifested as such on earth. 
In the Aramaic part of Daniel the occurrences of ?קר? all have Nebuchadnezzar as their object, with only one exception in Daniel 7:13. Here the 'Son of Man' receives יקָ' from God, designated as the 'Ancient of days'. The 'son of man' may be seen as an individual who represents the oppressed Israelites. His receiving a throne beside the 'Ancient of days' is an indication that he somehow belongs to the identity of Israel's God. Ezekiel 1 and 8 form the background of this 'son of man' portrayal and his divine identity.

Chapter 4. With the exception of 39:21 we find all occurrences of כָָּ with YHWH as its object in chapters 1-3, 8-11 and 40-48. 39:21

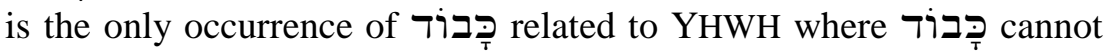
be understood as a hypostasis.

The vision of the פָָּ of YHWH and the prophet's call for office

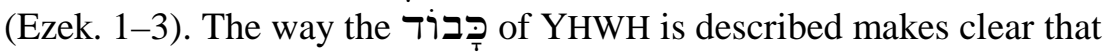
whereas it is ultimately beyond description, paradoxically and at the same time it is actually and really seen by the prophet.

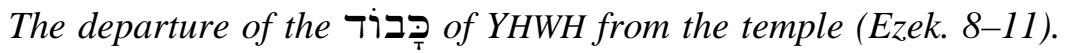
The emphasis here is on the profaning of the temple. The YHWH departs from the temple because of the people's sins. 'Purity' characterises the ethic of Ezekiel: Israel's moral sins are portrayed in terms of impurity. Chapters $8-11$ have a chiastic structure. The centre part is the actual departure of the כָּב סבוֹד

The preparation for the return of the כָָּ כָ of YHWH (Ezek. 34-39).

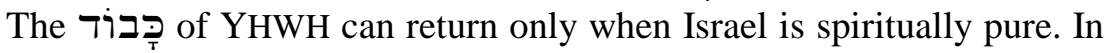
chapters 34-37 Israel's spiritual transformation is described. It is seen as solely the work of YHWH. We no longer come across the call to repentance in these chapters. It is YHWH himself who causes Israel to repent. It is remarkable that from Ezekiel 34 the name Jerusalem is no longer used.

Chapter 38-39 describe the attack of Gog king of Magog on Israel after the return of the exiles with references to memories of the past. The victory over Gog is YHWH's work alone and Israel does not

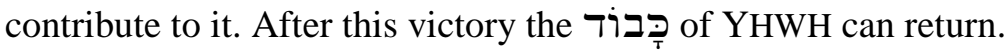

The return of the book's final vision is that the heavens will come down to the earth. The temple described in Ezekiel 40-42 has a heavenly character. The aim of worship in it is to connect heaven and earth. Both the structure of the new temple, in which the square is of special importance, and

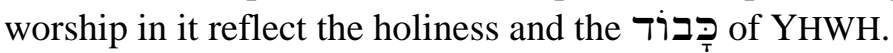


The return is the crown and climax not only of the final vision but also of the book as a whole, since the כָָּ כָרוֹ leave the temple. It is remarkable that never in the description of the

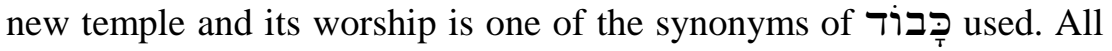
emphasis here is on the כָָּ כָוֹד of YHWH itself.

Chapter 5. Ben Sira's characterisation of Ezekiel as the prophet who

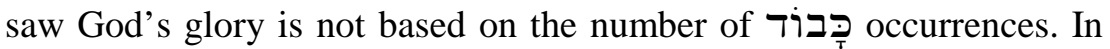

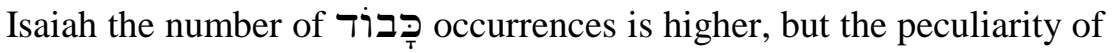

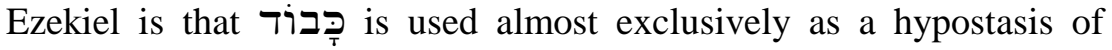
YHWH. Ezekiel's description of the כָָּ כָוֹד of YHWH is more elaborate than any other Old Testament writer's, and it highlights the dual and paradoxical nature of the divine description and being potentially visible. This research highlights especially the importance of the visible aspect. 